\title{
STUDIES ON ARBUSCULAR MYCORRHISATION OF PAPAYA
}

\author{
W. SHARDA KHADE and B. F. RODRIGUES ${ }^{1}$ \\ Darshan Apts, Vidhyanagar Colony, Carenzalem Post, Miramar, Panaji, Goa 403 002, India \\ ${ }^{1}$ Department of Botany, Goa University, Taleigao Plateau, Goa, India 403206
}

(Received 11 January, 2009; accepted 1 June, 2009)

\begin{abstract}
Carica papaya L. is known to exhibit a strong growth response to colonisation by arbuscular mycorrhizal fungi; yet it is generally believed that mycorrhizal growth effects are primarily nutritionally mediated and are inversely related to improved soil fertility, especially available soil $\mathrm{P}$, which affects the fungus symbiotic effectiveness. This study was, therefore, undertaken to evaluate the influence of selective arbuscular mycorrhizal fungi on vegetative growth of Carica papaya L. Studies were carried out in India on mycorrhization of Carica papaya var. Surya seedlings. The experiment comprised of un-inoculated seedlings, seedlings inoculated with Glomus intraradices, seedlings inoculated with Glomus mosseae and seedlings inoculated with mixed inoculum [Glomus intraradices + Glomus mosseae]. Inoculation with arbuscular mycorrhizal fungi significantly $(\mathrm{P}<0.05)$ increased all the growth parameters viz., plant height, stem girth, leaf area and root length. Mycorrhizal plants exhibited significant increase in fresh and dry weights of shoot and root systems. A higher root: shoot ratio was also observed in mycorrhizal plants than the control plants. Glomus mosseae was the most effective species of arbuscular mycorrhizal fungi, recording the highest root colonisation and exerting profound influence on growth of papaya.
\end{abstract}

Key Words: Arbuscular mycorrhizal fungi, Glomus mosseae, Glomus intraradices

\section{RÉSUMÉ}

Carica papaya L.est caractérisé par une forte croissance en réponse à la colonisation des champignons mycorrhiziens arbusculaires ; de même il est généralement admis que les effets de la croissance des champignons mycorhiziens jouent un rôle principalement nutritionnel et sont inversement liés à l'amélioration de la fertilité du sol, spécialement à la disponibilité en $\mathrm{P}$ dans le sol, ce qui affecte l'efficacité symbiotique du champignon. Cette étude a été entreprise pour évaluer l'influence de la sélectivité des champignons mycorhiziens à arbuscules sur la croissance végétative de Carica papaya L. Des études ont été faites en Inde sur la mycorhization des plantes de Carica papaya var.Syria. L'expérience était composée de plantes non inoculés, de plantes inoculés avec Glomus intraradices et des plantes avec l'inoculum mixte (Glomus intraradices + Glomus mosseae). L'inoculation par des champignons mycorhiziens à arbuscules a montré une augmentation significative $(\mathrm{P}<0.05)$ de tous les paramètres de croissance à savoir la hauteur de plantes, le diamètre de la tige, la surface foliaire et la longueur des racines. Les plantes avec mycorhizes ont montré une augmentation significative de la surface foliaire et de la longueur des racines. Egalement, le rapport pousse-racines a été plus élevé chez les plantes avec mycorhizes que celles sans mycorhizes. Glomus mosseae a été l'espèce la plus efficace de mycorhizes à arbuscules, ayant enregistré un grand nombre de racines colonisées et une grande influence sur la croissance du papaya.

Mots Clés: Champignons à mycorhizes arbusculaires, Glomus mosseae, Glomus intraradices 


\section{INTRODUCTION}

Carica papaya L. is known to exhibit a strong growth response to colonisation by arbuscular mycorrhizal fungi (Ramirez, 1975; Sukhada, 1989). It is well documented that mycorrhizal growth effects are primarily, nutritionally mediated and are inversely related to improved soil fertility, especially available soil $\mathrm{P}$, which affects the fungus symbiotic effectiveness (Rosalind Padma and Kandaswamy, 1990; Sukhada, 1992). Recent studies have confirmed these findings and have demonstrated the importance of arbuscular mycorrhizal symbiosis to papaya in low fertility soils (Martins, 2000). Also, they have elucidated their mycorrhizal status with respect to glucosinolate patterns (Vierheilig et al., 2000) and investigated the effect of arbuscular mycorrhizal fungi on leaf water potential and ethylene levels under stressed conditions (Cruz, 2000). Mamatha et al. (2002) have observed that papaya trees respond to inoculation with efficient arbuscular mycorrhizal fungi reducing the need for $\mathrm{P}$ fertilisation at least until the start of production. Kuwada et al. (2006) also reported that root colonisation of papaya was markedly stimulated by the application of red and green algal extracts. On the other hand, Khade and Rodrigues (2009) reported increased in elemental $\mathrm{P}$ and $\mathrm{K}$ in papaya plants inoculated with arbuscular mycorrhizal fungi. Similar studies carried by the earlier workers on papaya are summarised in Table 1.

The widespread occurrence of arbuscular mycorrhizal fungi in soils throughout tropical and temperate regions has sometimes led to the notion that inoculation of soils with arbuscular mycorrhizal fungi is not essential. However, inoculation is necessary where the fungi have been eliminated or their populations are reduced by pesticide application, fumigation, erosion, or other forms of soil disturbance. In some instances, indigenous arbuscular mycorrhizal fungi may either express their symbiotic effectiveness after a prolonged lag phase, or their inherent effectiveness may be too low, and thus this needs to be preempted by more aggressive, highly effective arbuscular mycorrhizal fungal inocula (Habte and Fox, 1989).

Arbuscular mycorrhizal fungi play crucial roles in agricultural situations, including: (i) agricultural systems in which the high P-fixing capacities of soils and the unavailability or high cost of $\mathrm{P}$ fertiliser limits crop production, (ii) situations in which it is essential to reduce soil fertiliser application rates significantly because of environmental concerns, and (iii) situations in which phosphate rock is readily available and used instead of super phosphate (Habte, 2000).

In the view of tremendous potential for arbuscular mycorrhizal fungi in maintaining sustainability of agro-based ecosystem, studies on the effect of arbuscular mycorrhizal fungi on growth of papaya would provide information essential to attempt to use these fungi in environmental conservation (Allen, 1991), biotechnology (Mulongoy et al., 1992) or in sustainable agriculture (Bethlenfalvavy and Linderman, 1992). This study was, therefore, undertaken to evaluate the influence of selective arbuscular mycorrhizal fungi on vegetative growth of Carica papaya L.

\section{MATERIALS AND METHODS}

Plant material. Seeds of Carica papaya var. Surya were procured from Indian Institute of Horticultural Research (IIHR), Bangalore. Surya is gynodioecious, high yielding (50-65 kg plant $^{-1}$ ) variety and is a progeny from the cross between Sunrise Solo x Pink Flesh Sweet released by IIHR, Bangalore. To date no literature exits on its mycorrhization.

Fungus material. Sand based pure cultures of Glomus mosseae (Nicol. \& Gerd.) Gerd. \& Trappe and G. intraradices Schenck \& Smith containing extramatrical chlamydospores, colonised root segments containing mycelium and vesicles were obtained from The Energy Research Institute (TERI), New Delhi. The inoculum of each culture consisted of 30 spores $2 \mathrm{~g}^{-1}$ moist soil.

Growing conditions. The experiment was conducted for four months (May 2002- August 2002) in a poly-house in agriculture farm located at Mapusa, North Goa. The relative humidity during the study period ranged from 84 to $93 \%$. Maximum temperatures in May and August 2002 are $31.60 \mathrm{C}$ and $29.3{ }^{\circ} \mathrm{C}$ respectively. While 
TABLE 1. Studies on effects of arbuscular mycorrhizal inoculation in Carica papaya $L$.

\begin{tabular}{|c|c|c|c|}
\hline Authors & Years & AM fungal species & Parameters studied \\
\hline Ramirez et al. & 1975 & $\begin{array}{l}\text { Glomus calospora, Glomus } \\
\text { hetrosporum, Glomus } \\
\text { macrocarpus }\end{array}$ & Growth \\
\hline Rosalind Padma and Kandaswamy & 1990 & $\begin{array}{l}\text { Glomus mosseae, Glomus } \\
\text { fasciculatum Gigaspora } \\
\text { margarita }\end{array}$ & Growth, phosphorus and nitrogen \\
\hline Sukhada & 1992 & $\begin{array}{l}\text { Glomus mosseae, Glomus } \\
\text { fasciculatum }\end{array}$ & $\begin{array}{l}\text { Growth, phosphorus, nitrogen and Zn } \\
\text { Root phosphatase activity }\end{array}$ \\
\hline Sukhada & 1995 & $\begin{array}{l}\text { Glomus mosseae, Glomus } \\
\text { fasciculatum }\end{array}$ & Uptake of P labeled super phosphate \\
\hline Reddy et al. & 1996 & $\begin{array}{l}13 \text { arbuscular mycorrhizal } \\
\text { fungal species }\end{array}$ & Growth, biomass, P \& Zn content \\
\hline Cruz et al. & 2000 & Gigaspora margarita & $\begin{array}{l}\text { Growth, leaf water potential, level of } \\
\text { ethylene under stress conditions }\end{array}$ \\
\hline Martins et al. & 2000 & $\begin{array}{l}\text { Glomus clarum. Glomus } \\
\text { macrocarpum }\end{array}$ & Biomass, $P$ content-phenolic compounds \\
\hline Trindade et al. & 2000 & Glomus etunicatum & Growth-10\% manure \\
\hline Vierheilig et al. & 2000 & $\begin{array}{l}\text { Glomus mosseae, Glomus } \\
\text { intraradices Gigaspora rosea }\end{array}$ & Glucosinolate patterns \\
\hline Trindade et al. & 2001 & $\begin{array}{l}\text { Glomus clarum, Gigaspora } \\
\text { margarita }\end{array}$ & Mycorrhizal dependency \\
\hline Mamatha et al. & 2002 & $\begin{array}{l}\text { Glomus mosseae, Glomus } \\
\text { caledonium with or without } \\
\text { Bacillus coagulans }\end{array}$ & $\begin{array}{l}\text { Growth, P uptake, yield and AM } \\
\text { colonisation levels }\end{array}$ \\
\hline Khade and Rodrigues & 2009 & $\begin{array}{l}\text { Glomus intraradices (GI) } \\
\text { Glomus mosseae (GM) Mixed } \\
\text { inoculum (GI+ GM) }\end{array}$ & $P \& K$ \\
\hline
\end{tabular}

minimum temperatures in May and August 2002 are $25.4{ }^{\circ} \mathrm{C}$ and $24.1^{\circ} \mathrm{C}$ respectively.

- Throughout the experimental period, papaya plants were watered thrice a week and fertilised with Hoagland's nutrient solution without phosphorus (Hoagland and Arnon, 1935), at an interval of fifteen days.

Raising of seedlings. Seeds of papaya were sown in plastic trays with sterilised nursery soil (sand soil mixture, 1:1). Garden soil was sterilised for two hours daily at 15lb pressure for three consecutive days to eliminate naturally occurring endophytes and other contaminants.

The soil used for the experiment was low in available phosphorus (6 kg ha-1) (Brays method, 1945) at pH 6.1 and electrical conductivity $0.06 \mathrm{~m}$ mhos $\mathrm{cm}^{-1}$ (conductivity meter, CM-180, Elico). Total nitrogen (Jackson, 1971) and exchangeable potassium (Hanway and Heidel, 1952) was $0.4 \%$ and $80 \mathrm{~kg} \mathrm{ha}^{-1}$, respectively. Organic carbon content (Walkley and Black method, 1934) was 
also low (0.42\%). Available $\mathrm{Zn}^{2+}, \mathrm{Cu}^{2+}, \mathrm{Fe}^{2+}$ and $\mathrm{Mn}^{2+}$ (Lindsay and Norvell, 1978) concentrations were 2.67, 3.84, 2.63, and 19.5 ppm, respectively. Seedlings were maintained in plastic trays for one month.

Inoculation with arbuscular mycorrhizal fungi. Seedlings of uniform length $(10 \mathrm{~cm})$ were selected for inoculation with arbuscular mycorrhizal fungi at the end of one month (Fig. 1A). The experiment comprised of four treatments and each treatment had fifteen replicates. The treatments were: Treatment 1 (C) - Un-inoculated Carica papaya var. Surya seedlings; Treatment 2 (GI) - Carica papaya var. Surya seedlings inoculated with G. intraradices; Treatment 3 (GM)- Carica papaya var. Surya seedlings; inoculated with G. mosseae; and Treatment 4(GI + GM) - Carica papaya var. Surya seedlings inoculated with mixed inoculum $G$. intraradices $+G$. mosseae.

Nursery polythene bags of $0.5 \mathrm{~kg}$ capacity were filled with sterilised soil up to $75 \%$ of their volume. A small pit was made into soil and $5 \mathrm{~g}$ of inoculum was placed at a depth of $5 \mathrm{~cm}$. Papaya seedling was then placed in this pit and layered with sterilised soil. One seedling was planted per bag. In the case of GI + GM inoculation, equal quantity (75 g each) of inoculum of $G$. intraradices Schenck \& Smith and G. mosseae were mixed thoroughly and then $5 \mathrm{~g}$ of inoculum added to each nursery bag. Control plants were inoculated with autoclaved inoculum. The plants were maintained for one and half months (45 days) in sterilised soil.

Transplantation of seedlings in unsterilised soil. After 2.5 months of growth (76 days), papaya seedlings were transferred to nursery polythene bags of $3 \mathrm{~kg}$ capacity, containing unsterilised nursery soil with low nutrient status as mentioned earlier. The plants were further maintained for a period of 45 days. The experiment was terminated at end of 123 days and papaya plants were subjected to analysis for various parameters as follows.

Estimation of root colonisation of arbuscular mycorrhizal fungi. Three plants per treatment were randomly selected for detecting the presence of arbuscular mycorrhizal colonisation. Papaya roots were thoroughly washed with tapwater, cleared with $10 \% \mathrm{KOH}$, acidified with $1 \mathrm{~N}$ $\mathrm{HCl}$ and then stained with $0.05 \%$ trypan blue (Phillips and Hayman, 1970). The degree of root colonisation was estimated using the slide method (Giovannetti and Mosse, 1980) and the values were expressed as percentages.

Plant growth measurements. Parameters viz., plant height, leaf area, stem girth, root length, fresh weights of root and shoot system, and dry weights of root and shoot systems were

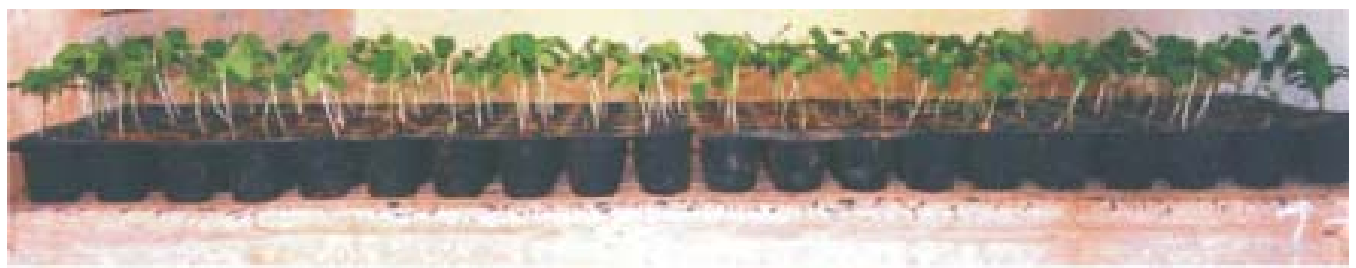

(A)

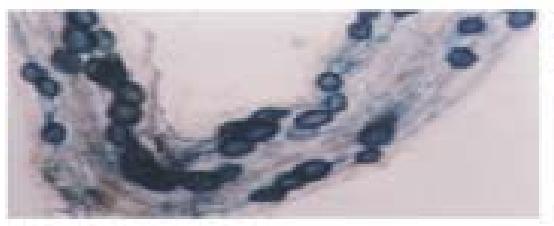

(B)

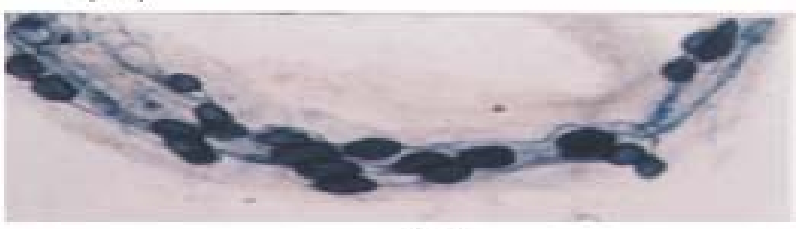

(C)

Figure 1. A) Seedlings of Carica papaya var. Surya prior to inoculation with arbuscular mycorrhizal fungi. B) Vesicular colonisation of AM fungi in papaya root ( $\mathrm{x} 400)$. C) Lipid filled vesicles attached to hyphae stained in trypan blue in papaya root (x 400). 
evaluated. There were five replicates for each treatments. Plant height was measured from the surface of soil to the highest point of the plant. Also, leaf lamina area was measured using a nonportable leaf area meter (Systronic 21). Stem girth was measured $2 \mathrm{~cm}$ above the surface of soil.

For fresh weights, plants were carefully removed from the polyethylene bags and the root and shoot portions were separated. Roots were thoroughly washed with tap-water to remove soil debris and then dried using blotting paper. Root lengths were recorded. The root and shoot systems were weighed separately. Further more, root and shoot potions were oven-dried separately at $70{ }^{\circ} \mathrm{C}$ for $72 \mathrm{hr}$ and dry weights recorded.

\section{RESULTS}

Microscopic observations revealed that in all the treatments, roots of papaya exhibited colonisation by arbuscular mycorrhizal fungi. Extensive mycorrhizal colonisation was observed in inoculated plants compared to the control. However, colonisation was confined only on first and second order roots; the first order being absorbing rootlets, according to the morphometric classification of roots (Fitter, 1982). In the present study, it was observed that the visible colonisation by arbuscular mycorrhizal fungi was confined to vesicles with dense lipid droplets and the adjacent hyphae which were, in most instances, weakly stained (Fig. 1 B and C).
At the harvest, maximum mean total root colonisation was recorded in plants inoculated with $G$. mosseae (84\%), followed by mixed inoculum (GI + GM) (72\%) and G. intraradices (58\%) with values given in parenthesis. The unsterilised nursery soil contained enough propagules of arbuscular mycorrhizal fungi, which developed a natural colonisation level of $22 \%$ in un-inoculated control after transplanting.

Data on the growth parameters of papaya plants are presented in Tables 2 and 3 . Inoculation with arbuscular mycorrhizal fungi significantly $(\mathrm{P}<0.05)$ increased plant height, stem girth, and leaf area (Fig. 2A), and root length (Fig. 2B) over the to control. Mycorrhizal plants exhibited significant $(\mathrm{P}<0.05)$ in fresh weight increases of shoot and root systems (Table 3 ). Also, significant $(\mathrm{P}<0.05)$ increases in dry weights of shoot and root system of mycorrhizal plants were recorded over the control plants. Additionally, comparatively higher root: shoot ratio was observed in mycorrhizal plants than control plants (Table 3).

In general, inoculated plants exhibited increased growth over the control plants. However, there was wide variation in the growth promoting efficiency of arbuscular mycorrhizal fungi (either singly or in combination). Glomus mosseae was the most effective species of arbuscular mycorrhizal fungi, exerting profound influence growth of Carica papaya var., Surya; followed by mixed inoculum (GI +GM) and $G$. intraradices (Fig. 3).

TABLE 2. Influence of arbuscular mycorrhizal fungi on plant height, root length, stem girth and leaf area of Carica papaya L. in Bangalore, India

\begin{tabular}{llccc}
\hline Treatments & \multicolumn{4}{c}{ YParameters } \\
\cline { 2 - 5 } & *Plant height $(\mathrm{cm})$ & *Root length $(\mathrm{cm})$ & *Stem girth $(\mathrm{cm})$ & *Leaf area $\left(\mathrm{cm}^{2}\right)$ \\
\hline Un-inoculated papaya (C) & $16.6(1.74)$ & $10.26(0.346)$ & $1.04(0.074)$ & $8.78(0.743)$ \\
Papaya inoculated with G. intraradices (GI) & $30.30(1.045)$ & $14.56(0.518)$ & $1.72(0.102)$ & $14.82(2.756)$ \\
Papaya inoculated with mixed inoculum of & $36.2(0.971)$ & $18.48(1.135)$ & $2.72(0.102)$ & $39.06(1.205)$ \\
G. intraradices and G. mosseae (MI) & & & & \\
Papaya inoculated with G. mosseae (GM) & $45.2(0.971)$ & $26.00(0.838)$ & $3.44(0.081)$ & $58.76(3.871)$ \\
C.D $(P<0.05)$ & 2.41 & 1.93 & 0.17 & 3.56 \\
\hline
\end{tabular}

${ }^{Y}$ Values presented are mean of five readings; Values in the parenthesis indicates $\pm 1 \mathrm{SE}$; ${ }^{*} \mathrm{~F}$ test significant at 0.05 level of probability 
TABLE 3. Influence of arbuscular mycorrhizal fungi on biomass_of Carica papaya L. in Bangalore, India

\begin{tabular}{|c|c|c|c|c|c|}
\hline \multirow[t]{2}{*}{ Treatments } & \multicolumn{5}{|c|}{ YParameters } \\
\hline & $\begin{array}{l}\text { *Shoot fresh } \\
\text { weight }(g)\end{array}$ & $\begin{array}{l}\text { *Root fresh } \\
\text { weight }(\mathrm{g})\end{array}$ & $\begin{array}{l}\text { *Shoot dry } \\
\text { weight }(g)\end{array}$ & $\begin{array}{l}\text { *Root dry } \\
\text { weight }(g)\end{array}$ & $\begin{array}{l}\text { Root/shoot } \\
\text { ratio }\end{array}$ \\
\hline Un-inoculated papaya (C) & $2.41(0.187)$ & $0.45(0.121)$ & $0.50(0.039)$ & $0.06(0.001)$ & 0.12 \\
\hline Papaya inoculated with $G$. intraradices (GI) & $6.38(0.747)$ & $1.21(0.129)$ & $0.73(0.043)$ & $0.10(0.004)$ & 0.13 \\
\hline Papaya inoculated with G. mosseae (GM) & $18.16(0.612)$ & $4.13(0.261)$ & $0.93(0.060)$ & $0.19(0.004)$ & 0.24 \\
\hline $\begin{array}{l}\text { Papaya inoculated with mixed inoculum of } \\
\text { G. intraradices and G. mosseae (MI) }\end{array}$ & $10.12(0.790)$ & $2.61(0.207)$ & $0.76(0.018)$ & $0.12(0.004)$ & 0.15 \\
\hline C.D $(P=0.05)$ & 0.93 & 0.367 & 0.095 & 0.008 & - \\
\hline
\end{tabular}

${ }^{\top}$ Values presented are mean of five readings; $V$ alues in the parenthesis indicates $\pm 1 \mathrm{SE}$; ${ }^{*} \mathrm{~F}$ test significant at 0.05 level of probability

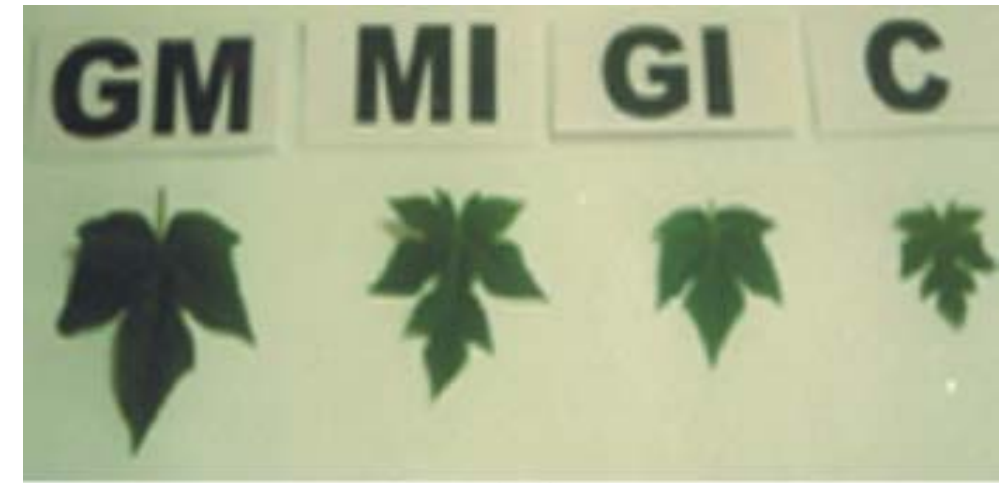

(A)

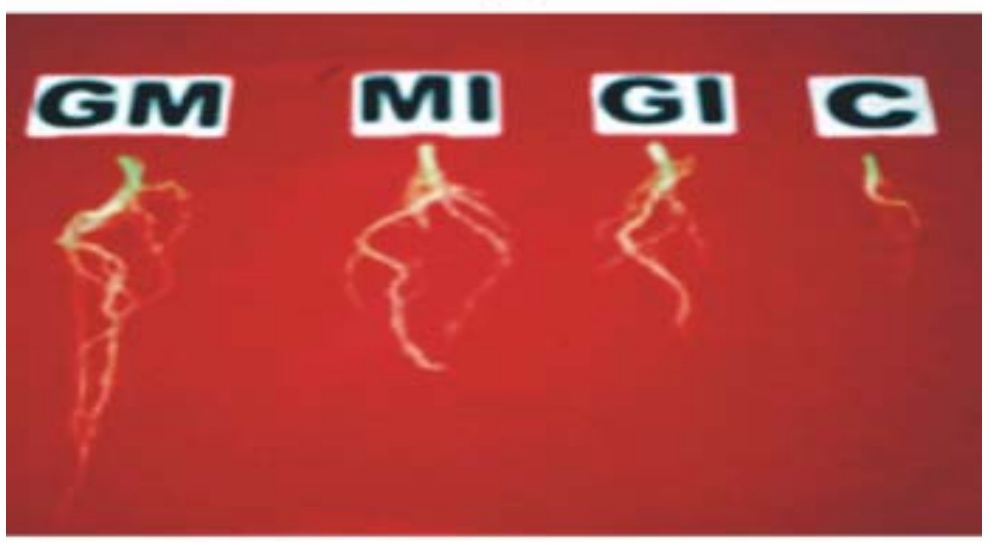

(B)

Figure 2. (A) Response of arbuscular mycorrhizal fungi on leaf lamina of Carica papaya var. Surya. (B) Response of arbuscular mycorrhizal fungi on root branching and root length of Carica papaya var. Surya in Bangalore, India. 


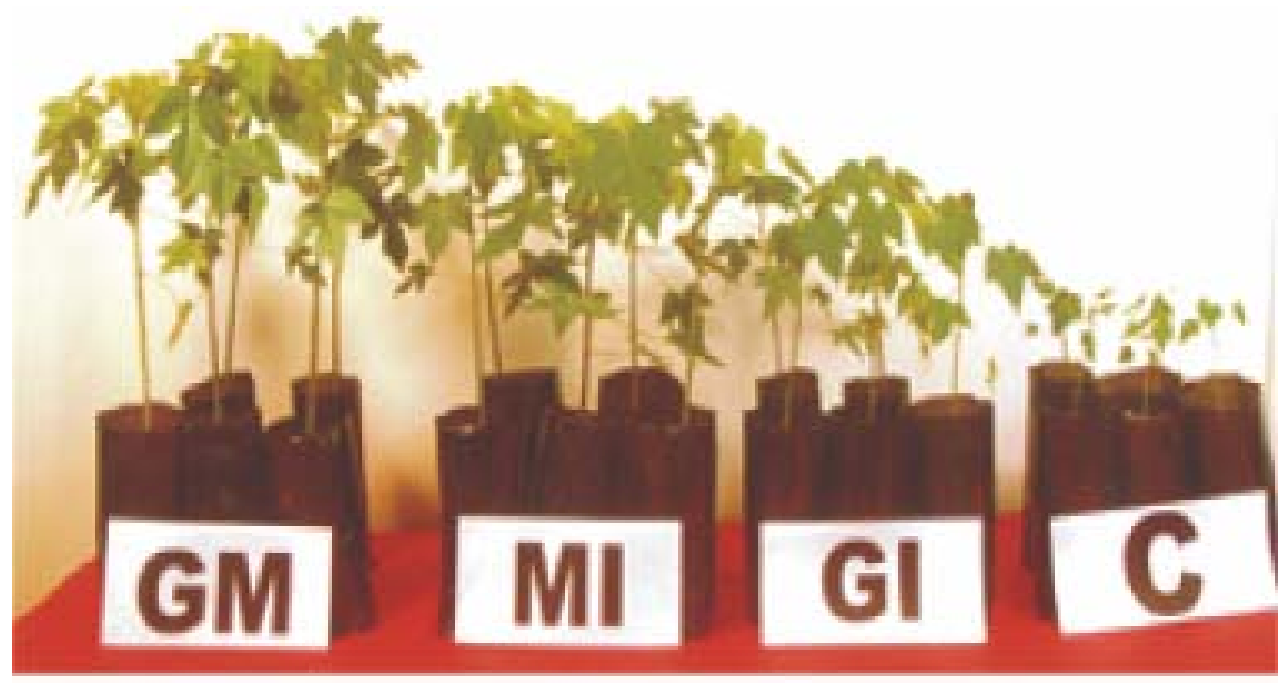

(A)

Figure 3. Effect of arbuscular mycorrhizal fungi on growth of Carica papaya L. in Bangalore, India.

\section{DISCUSSION}

The study clearly demonstrates the benefits of inoculation with arbuscular mycorrhizal fungi during early developmental stages of papaya grown in unsterelised soil under low levels of phosphorus. This potential of arbuscular mycorrhizal fungi to increase plant growth under low soil P has been well documented by several workers (Covey et al., 1981; Gnekow and Marschner, 1989; Graham et al., 1996).

Generally, inoculation studies with soil having indigenous mycorrhizal population are problematic since the colonisation caused by the introduced fungi cannot be conclusively attributed to the inoculants. This is especially so if there is doubt that the inoculum dose and infectivity have been significantly high (Niemi and Vestberg, 1992). In the present study, however, each inoculum dose per plant consisted of 75 spores, a substantial amount of colonised root fragments plus an unknown amount of external hyphae. Thus, root colonisation was not limited by lack of infective propagules. The fact that inoculation with arbuscular mycorrhizal fungi increased the overall plant growth more than uninoculated control, indicated that the inoculation of papaya was successful under the given experimental conditions. Cruz et al. (2000) also employed a similar number of spores of arbuscular mycorrhizal fungi for successful mycorrhization of papaya (var. Solo) plants in a controlled experiment.

The results obtained from the present study revealed differences among arbuscular mycorrhizal fungi in their ability to colonise the roots and influence growth in papaya plants. These inter-specific variation in the efficiency or growth promoting abilities of arbuscular mycorrhizal fungi could be attributed to the mechanism of mycorrhizal colonisation development (Sanders et al., 1977) or interaction between mycosymbionts and soil environment (Mosse, 1973).

Of the three mycorrhizal treatments tested for their efficiency, inoculation with $G$. mosseae significantly $(\mathrm{P}<0.05)$ increased all the study parameters ,followed by mixed inoculum, and in turn inoculation with $G$. intraradices. Thus, these results substantiate the hypothesis that not all combinations of host and endophyte have similar growth stimulating effects (Hayman, 1980), and this may be interpreted as a kind of functional host specificity or compatibility. Sukhada (1989) also reported $G$. mosseae to be more beneficial compared to G. fasiculatum in a glass house experiment where papaya (cv. Coorg Honey Dew) seedlings were inoculated in sterilised acidic soil 
and then transplanted to unsterile soil with varying levels of phosphorus. Reddy et al. (1996) screened the efficiency of 13 arbuscular mycorrhizal fungi in papaya plants grown in acidic unsterile soil amended with two percent organic matter, and reported that G. mosseae (ICRSAT) was the most efficient fungus for improving growth and nutrition of papaya.

Although it has been shown repeatedly that the amount of colonisation by arbuscular mycorrhizal fungi is not always correlated with efficiency (Yosef et al., 1984; Declerck et al., 1995), the present study appears to demonstrate a relationship between extent of colonisation and mycorrhizal efficiency. Plants inoculated with $G$. mosseae recorded the highest total root colonisation and maximum plant growth, followed by mixed inoculum (GI + GM) and $G$. intraradices. These results are in agreement with earlier findings of Sanders et al. (1977), who reported that arbuscular mycorrhizal fungi which are more effective in increasing growth, colonise plants more rapidly and extensively. Similarly, Miller et al. (1989) revealed that apple plants inoculated with $G$. mosseae and $G$. mosseae $+G$. macrocarpum recorded higher root colonisation and growth rates than plants inoculated with $G$. macrocarpum only.

Another factor undoubtedly important in explaining higher symbiotic efficiency of $G$. mosseae, but not estimated in this study, could be the amount or intensity of hyphal distribution in the soil. If the extramatrical hyphae are correlated with intramatrical hyphae (Tisdall and Oades, 1979), then the differences in the fungal species may be due to differences in the volume of soil explored (Miller et al., 1985).

Control plants of papaya were colonised by indigenous mycorrhizal and recorded lower root colonisation than the plants inoculated with selected mycorrhizal fungi; this is in agreement with the findings Vestberg (1992) and de Silva et al. (1996) in strawberry. Low levels of root colonisation in control plants indicated that the nursery soil had few indigenous fungi at low inoculum density (Ragupathy and Mahadevan, 1995) and that these indigenous fungi may have influenced the growth of control plants (de Silva et al., 1996) after transplantation in unsterile soil. However, inoculated plants had an added advantage over the indigenously colonised plants since they were colonised before transplanting (de Silva et al., 1996).

In this study, greater shoot length of inoculated plants was accompanied by larger leaf area, increased stem girth and root length compared to control plants in unsterile acidic soil, with low phosphorus. This is in agreement with the work of Plenchette et al. (1981) and Reddy et al. (1996) who reported similar growth response in apple and papaya inoculated with arbuscular mycorrhizal fungi grown in unsterile acidic soil with similarly low levels of phosphorus. The study also supports the findings of Onkarraya and Mohandas (1993) that presented improved height and root length of mycorrhizal Citrus under similar set of experimental conditions.

Ramirez et al. (1975) reported increased shoot length of papaya plants inoculated with Scutellospora calospora and G. macrocarpum, and the plants were taller than plants inoculated with $S$. heterogama, and the uninoculated controls after 40 days of sowing. Sukhada (1989; 1992) also reported increased in plant height of Carica papaya cv. Honey Dew inoculated with G. mosseae and G. fasiculatum under varying levels of phosphorus, after 5 months of growth in a glass house.

Rosalind Padma and Kandaswamy (1990) recorded $25.47 \%$ increase in plant height of papaya after 90 days of growth by application of $75 \%$ of recommended dose of phosphorus along with mixed inoculum (G. mosseae + G. fasciculatum + Gigaspora margarita). Thus, the increased heights in mycorrhizal plants could be due to the fact that mycorrhiza can cause earlier resumption of shoot apical growth (Azcoñ- Aguilar and Barea, 1997).

Arbuscular mycorrhizal fungi are known to induce morphological modifications in the host plant root system and a more branched root system has been observed in mycorrhizal plants of different herbaceous and woody species (Berta et al., 1995). In the present study, mycorrhizal inoculation of papaya increased the length of the taproot and the lateral roots of first and second order. This is in agreement with Bhattacharaya et al. (2002) who studied the changes in root development patterns of sweet orange inoculated with G. mosseae, G. fasciculatum and 
Gigaspora margarita under acidic soil with low levels of phosphorus.

Papaya (var. Surya) plants inoculated with mycorrhizal fungi also recorded increased biomass compared to uninoculated controls. The most significant response was exhibited in plants inoculated with G. mosseae. These observations support the earlier findings of Reddy et al. (1996) who reported that $G$. mosseae (ICRISAT) was the most efficient fungus for improving plant biomass of papaya plants. Jaizme-Vega and Azcoñ (1995) reported $G$. fasiculatum to be the most efficient fungus in improving growth of papaya, pineapple and banana under green house and field conditions. Rosalind Padma and Kandaswamy (1990) reported increase in plant biomass of papaya after 90 days of growth by application of $75 \%$ of recommended dose of phosphorus along with mixed inoculum ( $G$. mosseae $+G$. fasciculatum + Gigaspora margarita) than control plants.

In the present study, the dry weights of inoculated plants were significantly greater than control plants, in soil of low $P$ levels with acidic $\mathrm{pH}$. In a glass house experiment with soil of alkaline $\mathrm{pH}$ and varying $\mathrm{P}$ levels, Menge et al. (1978) reported significantly greater dry weights in mycorrhizal citrange and sour orange seedlings. In their study, maximum increase in dry weights were recorded at low levels of P viz., 0 and 6 ppm for mycorrhizal citrange (746 and $300 \%$ ) and 947 and $1089 \%$ for sour orange. Similarly, Sukhada (1997) reported increased accumulation of dry matter in mycorrhizal papaya (cv. Honey Dew) in a glass house experiment, where seeds were directly sown in soil treated with arbuscular mycorrhizal fungi. She reported that G. mosseae was more efficient than G. fasiculatum in improving plant dry matter.

In an earlier experiment comparing the efficacy of arbuscular mycorrhizal fungi under sterile and unsterile soil, Sukhada et al. (1995) reported that papaya plants inoculated with $G$. mosseae exhibited an increased dry matter (26.6\%) than $G$. fasiculatum (4.3\%) under sterile conditions. However, in unsterile soil, G. fasciculatum recorded higher accumulation of dry matter (29.5\%) compared to G. mosseae (26.3\%). de Silva et al. (1996) also recorded 70\% more dry matter in mycorrhizal strawberry relative to control plants.
Usually, mycorrhizal plants are known to exhibit lower root/shoot ratio than control plants in response to greater increment of shoot mass relative to root mass (Onkarayya and Mohandas, 1993). Estrada Luna et al. (2000) reported comparable values between the root/shoot ratios of mycorrhizal versus non-mycorrhizal micropropagated guava plantlets after 18 weeks of growth. However, the present study registered higher root/shoot ratios in mycorrhizal papaya at the end of 4 months of growth. This could be due to higher dry weight of mycorrhizal plants than control plants. de Silva et al. (1996) reported similar results in strawberry after 90 days of growth.

The shift in root length and shoot dry weight ratios is a typical response to improved $\mathrm{P}$ nutrition in both mycorrhizal and non-mycorrhizal plants. In mycorrhizal plants, the $\mathrm{P}$ concentrations per unit dry weight are higher, thus, $\mathrm{P}$ use efficiency is lower than non-mycorrhizal plants (Marschner and Dell, 1994). This indicates that other growth factors (carbohydrates, mineral nutrients ) become limiting or that in mycorrhizal root systems the feed-back regulation between nutrient uptake rates and shoot demand are less well-regulated than in non-mycorrhizal plant systems (Douds et al., 1988).

\section{ACKNOWLEDGEMENTS}

Shri. Waman M. Khade Ex-director of Agriculture Department, and the Directorate of Agriculture State Government of Goa are thanked for assistance to carry out research work.

\section{REFERENCES}

Allen, M. F. 1991. The ecology of mycorrhizae. Cambridge University Press, Cambridge, U.K. Azcón-Aguilar, C.A. and Barea, J.M. 1997. Applying mycorrhiza biotechnology to horticulture : significance and potentials. Scientia Horticulture 68:1-24.

Berta, G., Trotta A., Fusconi, J.E ., Hooker, D ., Munro, M., Atkinson, M., Giovennetti, S ., Morinl, P ., Fortuna, B. , Gianinazzi-Pearson, V. and Gianinazzi, S. 1995. Arbuscular mycorrhizas induces changes to plant growth 
and root system morphology in Prunus ceraciferah. Tree Physiology 15: 281-293.

Bhattacharya, P.M. , Paul, A.K., Saha, F. and Chaudhuri, S. 2002. Changes in the root development pattern of bamboo and orange plants upon arbuscular mycorrhization. Mycorrhiza News 14:15-18.

Bethlenfalvay, G. J. and Linderman, R.G. 1992. Mycorrhizae in Sustainable Agriculture. ASA, Special publication, Madison, WI. 124pp.

Bray, R. H. and Kurtz, L.T. 1945.Determination of total organic carbon and available forms of phosphorus in soils. Soil Science 59: 39-45.

Covey, R.P., Koch, B.L. and Larson H.J. 1981. Influence of vesicular arbuscular mycorrhizae on the growth of apple and corn in low phosphorus soil. Phytopathology 71:712 715.

Cruz, A.F., Ishir, T. and Kodoya, K. 2000. Effects of arbuscular mycorrhizal fungi on tree growth, leaf water potential and levels of 1aminocyclopropane-1 carboxylic acid and ethylene in roots of papaya under cultivated conditions. Mycorrhiza 10:121-123.

De, Silva A. and Patterson, K. 1996. Endomycorrhyzae and growth of sweet heart strawberry seedlings. HortScience 31(6):951954.

Declerck, S., Plenchette, C . and Strullu, L. 1995. Mycorrhizal dependency of banana (Musa accuminata, AAA group) cultivar. Plant and Soil 176:183-187.

Douds, D.D. JR., Johnson, C. R. and Koch, K. E. 1988.Carbon cost of the fungal symbiont relative to net leaf $\mathrm{P}$ accumulation is a splitroot VA mycorrhizal symbiosis.Plant Physiology 86: 491-496.

Estrada-Luna, A. A., Davies, JR. F. T. and Egilla, J. N. 2000. Mycorrhizal fungi enhancement of growth and gas exchange of micropropagated guava plantlets (Psidium guajava L.) during ex vitro acclimatization and plant establishment. Mycorrhiza 10:1-8.

Giovannetti, M., and Mosse, B. 1980. An evaluation of techniques for measuring vesicular arbuscular mycorrhizal infection in roots. New Phytologist 84: 489-500.

Gnekow, M. A. and Marschnes, H. 1989. Role of Va mycorrhiza in growth and mineral nutrition of apple (Malus pumila var. domestica) rootstock cuttings. Mycorrihza 119: 285-293.

Graham, G. H., Drowillard, D. L. and Hodge N.C. 1996. Carbon economy o0f sour orange in refference to different Gl. Species. Tree Physiology 16: 1023-1029.

Hayman, D.S. 1980. Mycorrhizal population of sowen pastures and native vegetation in Otago, New Zealand. New Zealand Journal of Agricultural Research 21: 271-276.

Hanway, J. J. and Heidal, H. 1952. Soil analysis method as used in Iowa State College Soil Testing Laboratory. Iowa Agriculture 57: 131.

Hoagland, D. R. and Arnon, D. I. 1935. The water culture anallised for growing plants without soil. California Agricultural Experimental Station Circular 347: 1- 35pp.

Jackson, M. L. 1971. Soil chemical analysis. Prentice Hall. New Delhi.

Jaizme-Vega, M.C. and Azcón, R. 1995. Responses of some tropical and subtropical cultures to endomycorrhizal fungi. Mycorrhiza 5 (3): 213-317.

Lindsay, W. L. and Norvel, W. A. 1978. Development of DPTA soil test for Zinc, Iron, Manganese and Copper. Soil Science Society American Journal 42:421- 488.

Martins, M. A., Gonclaves, G. F. D. E. and Soares, A.C.F. 2000. Effects of arbuscular mycorrhizal fungi associated with phenolic compounds on the growth of papaya. Pes. Agropec. Bra 35(7): 465-1471.

Marschner, H. and Dell, B. 1994. Nutrient uptake in mycorrhizal symbiosis. Plant Soil 159:89102.

Menge, J.A. , Labanauskas, C.K., Johnson, E. L. and Patil, R.G. 1978. Partial substitution of mycorrhizal fungi for phosphorous fertilization in the greenhouse culture of Citrus. Soil Science Society American Journal 42:926-930.

Miller, D.D., Domoto, P.A . and Walkar, C. 1985. Colonisation and efficacy of different endomycorrhyzal fungi with apple seedlings at two phosphorus levels. New Phytologist 100: 393-402.

Miller, D.D., Bodmer, M. and Schüepp, H. 1989. Spread of endomycorrhizal colonisation and 
effects on the growth of apple seedlings. New Phytologist 111(1): 51-59.

Mulongoy, K., Gianinazzi, S., Roger, P. A. and Dommergues, P. A. 1992. Biofertilizer: Agronomic and environmental impact and economics. In. Biotechnology: Economic and Social Aspects: Issues for Developing Countries, Eds. de silva, E.G., Rutledger, A.C. and Sasson A., UNESCO, Cambridge University Press, Cambridge U. K. 55-69 pp.

Mosse, B. 1973. Advances in the study of vesicular- Arbuscular mycorrhiza. Annual Review of Phytopathology 11: 171-196.

Niemi, M. and Vertberg, M. 1992. Inoculation of commercially grown strawberry with VA mycorrhizal fungi. Plant and Soil 144:133-141.

*Onkarayya, H., and Mohandas, S. 1993. Studies on dependency of Citrus root stocks to VAM inoculation in Alfisol soil. Adv. Hort. For. 3: 81-91.

Plenchette, C., Furlan, V. and Fortin, A. 1981. Growth stimulation of apple tree in unsterelised soil ynder field conditions with VA mycorrhiza inoculation. Canadian Journal Botany 59: 2003-2008.

Raghupathy, S. and Mahadevan, A. 1995. Effect of different mycorrhyzal treatment treatment on the growth of Peltophorum plerocarpum. In. Mycorrhizae: Biofertiliser for the future. Proceeding of the Third National Conferrence on Mycorrhiza, Eds. Adholeya, A.and Singh, S., TERI, New Delhi. (Rajkamal Electric Press),

Ramirez, B.N., Mitchell, D.J. and Schenck, N.C. 1975. Establishment and growth effects of three vesicular arbuscular mycorrhizal fungi on papaya. Mycologia 67: 1039-1041.

Reddy, B., Bagyaraj, D. J. and Mallesha B. C. 1996. Selection of efficient mycorrhizal fungi for papaya. Biological Agriculture Horticulture13 (1):1-6.

Rosalind Padma, T. M. and Kandaswamy, D. 1990. Effect of interactions between VAmycorrhizae and graded levels of phosphorus on growth of papaya (Carica papaya). In. Current Trends in Mycorrhizal Research, Eds.
Jalai, B. L., Chand H., Haryana Agricultural University, Hisar, India, 133-134pp.

Sanders, F.E.,Tinker, P.B., Black, R.L.B. and Palmerley, S.M. 1977. The development of endomycorrhizal root system. I. Spread of infection and growth promoting effects with four species of vesicular arbuscular endophyte. New Phytologist 78: 257-268.

Sukhada, M. 1989. Response of papaya (Carica papaya L.) to VAM fungal inoculation. In: Mycorrhizae for Green Asia (Jan 29-31, 1988), Eds. Mahadevan, A., Raman, N. and Natarajan, K., Madras, Alamer Printing works. Royapettah, Madras, 260-261pp.

Sukhada, M. 1992. Effect of VAM inoculation on plant growth, nutrient level and root phosphatase activity in papaya (Carica papaya C. V. Coorg Honey Dew ). Fertilizer Research 31: 263-267.

Sukhada, M. 1997. VA Mycorrhiza fungi for fruit Nursuries. In: Soil Microorganism sustainability, Eds. Khale R. D. and Bano R. , ISSBB, UAS, Banglore, 36-40pp.

Sukhada, M., Shivananda, T.N. and Iyenger, B.R.V. 1995. Uptake of 32P labelled superphosphate by endomycorrhizal papaya (Carica papaya cv. Coorg Honey Dew). Journal Nuclear of Agriculture 24(4): 30-31.

Tisdall, J.M. and Oades, J.M. 1979. Stabilization of soil aggregates by the root system of rye grass. Journal of Soil Research 17: 429-441.

Vierheilig, H., Bennett, R., Kiddle, R., Kaldorf M. and Ludwig-Muller J. 2000. Difference in glucosinolate patterns and arbuscular mycorrhizal status of glucosinolate containing plant species. New Phytologist 146(2): 343-352.

Walkley, A.J. and Black I. A. 1934.Estimation of soil organic carbon by chromic acid titration method. Soil Science 37: 29-38.

Yosef I.G., Trappe J.M. and Stebbin R.L. 1984. Effects of vesicular-arbuscular mycorrhizal and phosphorus on apple seedling. Journal of American Society of Hortticulture Science 190(1): 24-27. 